\title{
EFFECTS OF SHORT-TERM PRACTICE OF PRANAYAMA IN HEALTHY ASYMPTOMATIC INDIVIDUALS ON THE RESPIRATORY PARAMETERS
}

\author{
Satish $\mathrm{M}^{1}$, Basavaraj $\mathrm{R}^{2}$, Noor Jehan Begum ${ }^{3}$, Arun Kumar $\mathrm{S}^{4}$, Ramesh $\mathrm{K}^{5}$
}

\section{HOW TO CITE THIS ARTICLE:}

Satish M, Basavaraj R, Noor Jehan Begum, Arun Kumar S, Ramesh K. "Effects of Short-Term Practice of Pranayama in Healthy Asymptomatic Individuals on the Respiratory Parameters". Journal of Evolution of Medical and Dental Sciences 2014; Vol. 3, Issue 10, March 10; Page: 2579-2585,

DOI: $10.14260 /$ jemds/2014/2176

ABSTRACT: BACKGROUND: Pranayama is an art of controlling the life force of breath. It produces many systemic psycho-physical effects in the body, besides its specific effects on the respiratory functions. It is claimed that practice of 'pranayama' is one of the ways to achieve this goal of physical and mental health. 'Regular practice of pranayama has found to be helpful in developing a healthy body and a sound mind. Several studies have shown the beneficial effects of pranayama practice on respiratory parameters in patients with respiratory disorders, especially asthmatics. The present study was done to find out whether short-term practice of pranayama has any additive effects on respiratory parameters of normal healthy persons. METHODOLOGY: The present study was conducted in Department of Physiology, Vijayanagar Institute of Medical Sciences, Bellary on 200 medical and paramedical students comprising of both males and females, fulfilling the inclusion criteria. In the beginning they were given training in practice of pranayama, after which all the subjects practiced two types of pranayama for a total duration of 12 weeks. Lung parameters like Respiratory rate (R.R), Tidal volume $\left(V_{T}\right)$, Inspiratory reserve volume (I.R.V), Expiratory reserve volume (E.R.V), Vital capacity (VT), Forced expiratory volume in first second $\left(\mathrm{FEV}_{1}\right)$ and Peak expiratory flow rate (P.E.F.R) were recorded at the beginning and at the end of the 12 weeks study period. RESULTS: The subjects showed improved ventilatory functions, in the form of decrease in respiratory rate (R.R) and increase in Vital capacity (VT). Lung volumes like Tidal volume $\left(V_{T}\right)$, Inspiratory reserve volume (I.R.V) and Expiratory reserve volume (E.R.V) also showed significant increase. CONCLUSION: There was a statistically significant increase in all the above lung parameters in the regular yoga practitioners.

KEYWORDS: Pranayama, Respiratory rate, vital capacity, Peak expiratory flow rate, $\mathrm{FEV}_{1} \%$.

INTRODUCTION: To breathe is the first action we take as an autonomous being, and we continue to do so until we give up this body. From the first breath to the last breath; we exist dependent upon an energetic exchange between inner and outer environments. Without breath, we perish. We can survive for weeks without food, for days without water, but we will die if deprived of air for more than a few minutes. To live is to breathe. ${ }^{1}$

While breathing is fundamental, our life experiences can alter the pattern of this natural process, distorting its rhythm and flow. When this happens, whether brought about by stress or simply how one comes to inhabit one's body/mind, breath's life-affirming, energizing, and nourishing capacities are disrupted. This may result in physical, mental, emotional, and spiritual disharmonies. Unfortunately most people do not breathe in the right way. Shallow chest-restricted breathing is pandemic in our culture. Fast breathing or restricting the breath is a common and unhealthy response to physical or emotional pain or duress. We live in a time of tight bodies in tight clothes 
holding to tight schedules. The more we try to rigidly control, the more we constrict. The more we constrict, the less we breathe. ${ }^{1}$

Re-learning to breathe slowly and naturally can have tremendous benefit to overall health, energy, and outlook. The science of yoga speaks of "pranayama", which is a controlled breathing exercise. The word 'prana' in pranayama is translated as respiration which determines breath of life, vitality and energy. The word 'ayama' means stretch, expansion, prolongation, restrain or control' Thus pranayama is the art of prolongation and control of breath.

Pranayama helps in bringing conscious awareness to breathing and the reshaping of breathing habits and patterns. This has been found to improve a variety of conditions, including migraine headaches, chronic pain, hypertension, epilepsy, asthma, panic attacks, hyperventilation syndrome, menopausal hot flushes, and coronary heart disease. ${ }^{3}$ As a technique, pranayama can assume rather complex forms of breathing, but the essence of the practice is slow and deep breathing. Such breathing is economical because it reduces dead space ventilation.

It also refreshes air throughout the lungs, in contrast with shallow breathing that refreshes air only at the base of the lungs ${ }^{4}$. In a nutshell, breath is a dynamic bridge between body and mind, and pranayama, as a natural way of cleansing breath has been suggested as a route to healthy body and mind. And with increased awareness and interest in health and natural remedies, yogic techniques such as pranayama is gaining importance and becoming increasingly acceptable to the scientific community. Its value is seriously realized in today's dynamic, and stressful world. To meet the demands of the hectic lifestyle, one has to work hard. Stresses and strains are the obvious hazards of such a lifestyle. Pranayama suggests a life style which is free from stress and pain ${ }^{5}$. It makes the body and mind effective for leading a happy and healthy life.

METHODOLOGY: The present study was conducted on normal healthy medical and paramedical students, aged between 18 to 20 years studying in VIMS, Bellary. During this period 200 students (100 males and 100 females) participated in this study. The criteria for the inclusion of subjects in the study were

1. Subject's age group was between 18 to 20 years to eliminate the age related variations.

2. Subjects had to be healthy, without any known history of respiratory illness especially asthma, chronic sinusitis.

3. Subjects had to be free from any type of musculoskeletal impairment.

The purpose and importance of the study was explained to all the subjects, after which informed consent was taken from all the subjects for the study. Ethical clearance was obtained from the local ethical committee, VIMS, Bellary. Students taking part in the study at first underwent 2 weeks training where they were taught various types of pranayama techniques under expert guidance. During this period the subjects practiced pranayama twice daily for 30 minutes. After the training period, they were asked to practice two forms of pranayama: Anuloma Viloma for the first 5 weeks and Nadishodhana pranayama for 5 weeks.

The practice of the above mentioned breathing techniques was done by all the subjects under supervision for 30 minutes daily in the evening between $5: 30 \mathrm{pm}$ to $6: 00 \mathrm{pm}$ in the premises of department of physiology, Vijayanagar Institute of Medical Sciences, Bellary till the end of the study period. 
The following observations were made at the beginning of the study and at the end of 12 weeks of pranayama practice:

- Respiratory rate (R.R) was recorded at resting state, by counting the chest excursions in one minute using a stop watch.

- Other lung parameters like tidal volume ( $V_{T}$ or T.V), Inspiratory reserve volume (I.R.V), Expiratory reserve volume (E.R.V), Vital capacity (V.C), Forced expiratory volume in first second $\left(\mathrm{FEV}_{1} \%\right)$ were recorded using the Spirolyser

- $\quad$ Peak expiratory flow rate (P.E.F.R) was recorded using the Vitalograph peak flow meter. Statistical Analysis

As this study uses the same group to study the changes in lung parameters, before and after practice of pranayama, analysis of results was be made using student's paired 't' test.

\section{RESULTS:}

In the boys group, the following changes were recorded (Table1).

1. There was a significant reduction in the rate of respiration (R.R). The mean value decreased from $13.28+2.362$ breaths per minute to $9.79+1.788$ breaths per minute. The ' $t$ ' value was calculated to be 17.00 and $\mathrm{p}<0.001$ (Statistically significant).

2. Tidal volume $\left(\mathrm{V}_{\mathrm{T}}\right)$ showed an increase with the initial mean value of $466.75+36.937 \mathrm{ml}$ to a final mean value of $472.0+35.583 \mathrm{ml}$. The ' $\mathrm{t}$ ' value was found to be -3.778 and $p<0.001$ (Statistically significant).

3. Inspiratory reserve volume (I.R.V) showed a significant increase. The mean value increased from $2620+140.75 \mathrm{ml}$ to a final mean value of $2811+127.49 \mathrm{ml}$. The ' $\mathrm{t}$ ' value was -19.504 and $\mathrm{p}<0.001$ (Statistically significant).

4. Expiratory reserve volume (E.R.V) also showed an increase in the mean value. The mean value increased from $836.00+70.739 \mathrm{ml}$ to $945.75+71.338 \mathrm{ml}$. The ' $\mathrm{t}$ ' value was calculated to be 21.791 and $\mathrm{p}<0.001$ (Statistically significant).

5. There was a remarkable increase in vital capacity (V.C). The initial mean value was $3922.75+199.529 \mathrm{ml}$ to a final mean value of $4228.75+165.65 \mathrm{ml}$. The ' $\mathrm{t}$ ' value was found to be 28.703 and $\mathrm{p}<0.001$ (Statistically significant).

6. Forced expiratory volume in first second also showed significant increase, with the final mean value of $81.42+2.559 \%$ of F.V.C as compared to the initial mean value of $76.67+2.446 \%$ of F.V.C. The ' $t$ ' value was found to be -45.743 and $p<0.001$ (Statistically significant).

7. Peak expiratory flow rate (P.E.F.R) was also increased significantly. The mean value initially was $416.90+36.423$ Litres min while the final mean value was $498.2+30.364$ Litres $/ \mathrm{min}$ The ' $\mathrm{t}$ ' value was found to be -33.609 and $\mathrm{p}<0.001$ (Statistically significant).

In the girls group, similar changes were noticed, which are as follows (Table2).

1. The Respiratory rate (R.R) showed a significant decrease with the initial mean value of $12.54+2.298$ breaths per minute to a final mean value of $9.29+1.445$ breaths per minute. The ' $\mathrm{t}$ ' value was found to be 21.016 and $\mathrm{p}<0.001$ (Statistically significant).

2. Tidal volume $\left(\mathrm{V}_{\mathrm{T}}\right)$ showed an increase with the initial mean value of $441.00+49.431 \mathrm{ml}$ to a final mean value of $452.50+39.006 \mathrm{ml}$. The ' $\mathrm{t}$ ' value was found to be -4.604 and $p<0.001$ (Statistically significant). 
3. Inspiratory reserve volume (I.R.V) also showed an increase in the mean value. The mean value increased from $1698.0+75.435 \mathrm{ml}$ to $1909.75+83.703 \mathrm{ml}$. The ' $\mathrm{t}$ ' value was calculated to be 33.821 and $\mathrm{p}<0.001$ (Statistically significant).

4. Expiratory reserve volume (E.R.V) also showed an increase in the mean value. The mean value increased from $647.50+49.43 \mathrm{ml}$ to $721.50+52.23 \mathrm{ml}$. The ' $\mathrm{t}$ ' value was calculated to be -10.29 and $\mathrm{p}<0.001$ (Statistically significant).

5. Significant increase in Vital capacity (V.C) was noticed. The initial mean value was $2786.5+151.44 \mathrm{ml}$ to a final mean value of $3083.75+142.15 \mathrm{ml}$. The ' $\mathrm{t}$ ' value was found to be 14.31 and $\mathrm{p}<0.001$ (Statistically significant).

6. Forced expiratory volume in first second $\left(\mathrm{FEV}_{1}\right)$ was also increased significantly. The mean value initially was $75.04+2.534 \%$ of F.V.C while the final mean value was $80.09+2.094 \%$ of F.V.C. The ' $t$ ' value was found to be -40.133 and $p<0.001$ (Statistically significant).

7. Peak expiratory flow rate (P.E.F.R) showed remarkable improvement, with the final mean value of $416.20+24.112$ Litres/min as compared to the initial mean value of $361.00+23.506$ Litres/min. The ' $\mathrm{t}$ ' value was calculated and was found to be -32.767 and $p<0.001$ (Statistically significant).

DISCUSSION: There was significant decrease in rate of respiration among study subjects. Similar observations have been reported by other study6. Usually breathing is not a conscious event and is regulated automatically by the nervous system through the respiratory centers located in the medulla oblongata and pons. These are the dorsal and ventral group of neurons located in the medulla, the pneumotaxic center and the apneustic center located in the pons. The activity of these respiratory centers is in turn modified by supra-pontine influences, in a conscious human being. While the basic respiratory rhythm in normal situations is maintained by the impulses discharged by the dorsal group of neurons, the pneumotaxic center indirectly controls the duration of inspiration helps in relaying the supra-pontine impulses which promote voluntary inspiration and expiration. ${ }^{7}$

During daily practice of pranayamic breathing the basic activity of the bulbo-pontine complex is modified in such a way as to slow down its rhythm. Also by voluntarily prolonging the phase of inspiration and expiration, the respiratory muscles are stretched to their full extent and the respiratory apparatus is able to work to their maximal capacity. Thus after continuous practice of pranayama for few weeks, the bulbo-pontine complex is adjusted to the new pattern of breathing which is slower than its basal rhythm. ${ }^{8}$

Also there was significant increase in lung volumes like tidal volume, inspiratory reserve volume and expiratory reserve volume. The improvement in these parameters can be explained on the following basis.

a) There occurs strengthening of respiratory musculature after regular practice of pranayama, during which the lungs inflate and deflate to their fullest possible extent and the muscles are made to work to the maximal extent.

b) Secondly lung inflation near to the total lung capacity is a major physiological stimulus for the release of lung surfactant and prostaglandins into the alveolar spaces. These increases lung compliance and decreases bronchiolar smooth muscle tone respectively. ${ }^{7}$

In normal breathing, inspired air is not uniformly distributed and in erect posture the unit volume of lung is greater in the lower parts of lung than in the upper parts. In normal breathing after a particular degree of stretching or even before this, stretch receptors (situated in the walls of the 
alveoli) are stimulated and send information to the respiratory center so that exhalation sets in. But in pranayama there is continuation of the phase of inhalation with a strong voluntary control so that lungs are expanded considerably and the walls of the alveoli are stretched to the maximum extent. Thus the chest continues to get expanded under cortical control.

The stretch receptors are thus trained to withstand more and more stretching. This helps in holding the breath for a longer time. As the duration of breath holding during pranayama is gradually increased by the practice of pranayama so that the respiratory center is acclimatized to withstand higher and higher carbon-di-oxide concentrations in the alveoli and the blood. The central chemoreceptors, located in the medulla near the dorsal group of respiratory neurons are sensitive to the amount of carbon dioxide concentration in the blood.

The carbon dioxide stimulates these chemoreceptors which in turn send impulses to the respiratory center. The respiratory center which would have otherwise started exhalation is now helpless against the strong voluntary control from the cortex. The peripheral chemoreceptors which are sensitive to the lowered oxygen levels in the blood would also send strong stimulation to the respiratory center to start exhalation. As the carbon dioxide goes on accumulating, the pneumotaxic center tries to stimulate the expiratory center. The autonomic and reflex mechanism of respiration is far more powerful than the control from the higher center, which explains the inability to hold the breath for a longer time. The receptors however get acclimatized to the increased concentrations of carbon dioxide gradually by regular practice of pranayama. ${ }^{9}$

The Peak expiratory flow rate also showed significant increase. The cause for this could be again the fact that pranayama helps increase the lung compliance and relax the bronchiolar smooth muscles due to its effects on the release of surfactant and prostaglandins into the alveolar spaces. Also, pranayama with its calming effect on the mind can reduce emotional stresses, thereby withdrawing the bronchoconstrictor influences. ${ }^{8}$

This change in tidal volume can be explained on the following lines.

a. Other studies have incorporated pranayama practice in yoga schedule prescribed to the untrained normal volunteers. So, pranayama forms only part of the schedule. While yogic stretching exercises have without doubt beneficial effects on the whole body system, exclusive pranayama practice like adopted in the present study has more important and significant effects on the respiratory parameters ${ }^{10}$.

b. This observation is supported by another study published in Lancet in the year 1990. Stanescu and his colleagues ${ }^{11}$ reported that exclusive practice of pranayama on a regular basis has been shown to increase the lung volumes including tidal volume in normal healthy individuals.

CONCLUSION: There was decrease in respiratory rate (R.R) and increase Vital capacity (VT). There was an increment in the lung volumes Tidal volume $\left(\mathrm{V}_{\mathrm{T}}\right)$, Inspiratory reserve volume (I.R.V), expiratory reserve volume (E.R.V). Also there was a significant increase in Forced expiratory volume in first second $\left(\mathrm{FEV}_{1} \%\right)$ and Peak expiratory flow rate (P.E.F.R).

\section{REFERENCES:}

1. Barry Kapke. The Bodhiwork Institute in Petaluma, California "Breathe in breathe out". An article published in Massage \& Bodywork Magazine; Apr/May 2004: p 1.

2. B.K.S. Iyengar. "Light on pranayama", 19th edition. Harper Collins publishers. New Delhi; 2005. 
3. Donna Farhi, The Breathing Book. "Good Health and Vitality through Essential Breath Work". Henry Holt New York; 1996: p 6.

4. Bijlani R.L. Understanding Medical Physiology, 3rd edition. "The Yogic Practices: Asanas, Pranayamas and Kriyas". Jaypee Brothers Medical Publishers (P) Ltd. New Delhi-India; 2004: p 883-889.

5. Sri Swami Sivananda. "Easy steps to yoga". A divine life society publication world wide web (WWW) Edition; 2000: p1-30.

6. Murthy, Sahay, et al. "Effect of yoga on ventilatory functions in normal healthy volunteers". Lung India 1983; 1(5): p 189-192.

7. L. N Joshi, V. D Joshi and L. V Gokhale. "Effect of short term pranayama on breathing rate and ventilatory functions of lung". Indian J Physiology Pharmacology 1992; 36(2): p 105-108.

8. K. Makwana, N. Khirwadkar and H. C Gupta. "Effect of short term yoga practice on ventilatory function tests". Indian J Physiology Pharmacology 1988; 32(3): p 202-208.

9. Rachana Shirohi. "Effect of Nadishodhan pranayama on forced vital capacity". Yoga department, dev Sanskrit university, Haridwar. Unpublished manuscript.

10. K. N. Udupa, R.R. Singh and R. M. Settiwar. "Studies on the effect of some yogic breathing exercises (Pranayama) in normal persons". Indian J Medical Research 1975; 63(8): p 10621065.

11. Stanescu. D.C, Nemery. B, et al. "Yoga breathing exercises and bronchial asthma". Comment in The Lancet 1990 Nov; 336(8724): p 1192.

\begin{tabular}{|c|c|c|c|c|c|c|c|c|c|}
\hline \multirow{2}{*}{ Parameter } & \multicolumn{4}{|c|}{ Initial } & \multicolumn{4}{|c|}{ Final } & \multirow{2}{*}{$\begin{array}{l}\text { Statistical } \\
\text { significance }\end{array}$} \\
\hline & No & Mean & S.D & SEM & No & Mean & SD & SEM & \\
\hline $\begin{array}{l}\text { Respiratory rate } \\
\text { (per min) }\end{array}$ & 100 & 13.28 & 2.362 & 0.236 & 100 & 9.79 & 1.788 & 0.179 & $\begin{array}{c}\mathrm{t}=17.00 \\
\mathrm{p}<0.001 \\
\text { Significant }\end{array}$ \\
\hline $\begin{array}{l}\text { Tidal volume } \\
(\mathrm{ml})\end{array}$ & 100 & 466.75 & 36.937 & 3.694 & 100 & 472.0 & 35.583 & 3.558 & $\begin{array}{c}\mathrm{t}=-3.778, \\
\mathrm{p}<0.001 . \\
\text { Significant }\end{array}$ \\
\hline $\begin{array}{l}\text { Inspiratory } \\
\text { reserve volume } \\
(\mathrm{ml}) \\
\end{array}$ & 100 & 2620 & 140.75 & 14.08 & 100 & 2811 & 127.49 & 12.75 & $\begin{array}{c}\mathrm{t}=-19.504, \\
\mathrm{p}<0.001 . \\
\text { Significant }\end{array}$ \\
\hline $\begin{array}{l}\text { Expiratory } \\
\text { reserve volume } \\
(\mathrm{ml})\end{array}$ & 100 & 836.00 & 70.739 & 7.074 & 100 & 945.75 & 71.338 & 7.134 & $\begin{array}{c}\mathrm{t}=-21.791, \\
\mathrm{p}<0.001 \\
\text { Significant }\end{array}$ \\
\hline $\begin{array}{l}\text { Vital capacity } \\
\text { (ml) }\end{array}$ & 100 & 3922.75 & 199.529 & 19.95 & 100 & 4228.75 & 165.655 & 16.566 & $\begin{array}{c}\mathrm{t}=-28.703, \\
\mathrm{p}<0.001 \\
\text { Significant }\end{array}$ \\
\hline $\mathrm{FEV}_{1}(\%$ of $\mathrm{VC})$ & 100 & 76.67 & 2.446 & 0.245 & 100 & 81.42 & 2.559 & 0.256 & $\begin{array}{c}t=-45.743 \\
p<0.001 \\
\text { Significant }\end{array}$ \\
\hline PEFR Lit/min & 100 & 416.90 & 36.423 & 3.642 & 100 & 498.2 & 30.364 & 3.036 & $\begin{array}{c}\mathrm{t}=-33.609 \\
\mathrm{p}<0.001 \\
\text { Significant }\end{array}$ \\
\hline
\end{tabular}


No.-Size of the group S.D - Standard deviation S.E.M- Standard error of mean

\begin{tabular}{|c|c|c|c|c|c|c|c|c|c|}
\hline \multirow{2}{*}{ Parameter } & \multicolumn{4}{|c|}{ Initial } & \multicolumn{4}{|c|}{ Final } & \multirow{2}{*}{$\begin{array}{c}\text { Statistical } \\
\text { Significance }\end{array}$} \\
\hline & No & Mean & SD & SEM & No & Mean & SD & SEM & \\
\hline $\begin{array}{l}\text { Respiratory } \\
\text { Rate (per min) }\end{array}$ & 100 & 12.54 & 2.298 & 0.230 & 100 & 9.29 & 1.445 & 0.144 & $\mathrm{t}=21.016, \mathrm{p}<0.001$ \\
\hline Tidal volume (ml) & 100 & 441.00 & 49.431 & 4.943 & 100 & 452.50 & 39.006 & 3.901 & $\begin{array}{c}\mathrm{t}=-4.604, \mathrm{p}<0.001 \\
\text { Significant }\end{array}$ \\
\hline $\begin{array}{l}\text { Inspiratory reserve } \\
\text { volume (ml) }\end{array}$ & 100 & 1698.0 & 75.435 & 7.543 & 100 & 1909.75 & 83.703 & 8.370 & $\begin{array}{c}\mathrm{t}=-33.821, \mathrm{p}<0.001 \\
\text { Significant }\end{array}$ \\
\hline $\begin{array}{l}\text { Expiratory reserve } \\
\text { volume (ml) }\end{array}$ & 100 & 647.50 & 49.43 & 4.943 & 100 & 721.50 & 52.23 & 5.22 & $\begin{array}{c}t=-10.29, \\
p<0.001 \text { Significant }\end{array}$ \\
\hline Vital capacity (ml) & 100 & 2786.5 & 151.44 & 15.14 & 100 & 3083.75 & 142.15 & 14.22 & $\begin{array}{c}\mathrm{t}=-14.31, \mathrm{p}<0.001 \\
\text { Significant }\end{array}$ \\
\hline $\begin{array}{l}\mathrm{FEV}_{1} \\
(\% \text { of FVC) }\end{array}$ & 100 & 75.04 & 2.534 & 0.253 & 100 & 80.09 & 2.094 & 0.209 & $\begin{array}{c}\mathrm{t}=- \\
=-40.133 \mathrm{p}<0.001 \\
\text { Significant }\end{array}$ \\
\hline PEFR (Lit/min) & 100 & 361.00 & 23.506 & 2.351 & 100 & 416.20 & 24.112 & 2.411 & $\begin{array}{c}\mathrm{t}=-32.767 \mathrm{p}<0.001 \\
\text { Significant }\end{array}$ \\
\hline
\end{tabular}

No.-Size of the group S.D - Standard deviation S.E.M- Standard error of mean

\section{AUTHORS:}

1. Satish M.

2. Basavaraj R.

3. Noor Jehan Begum

4. Arun Kumar S.

5. Ramesh K.

\section{PARTICULARS OF CONTRIBUTORS:}

1. Assistant Professor, Department of Physiology, Vijayanagara Institute of Medical Sciences, Bellary.

2. Assistant Professor, Department of Physiology, Vijayanagara Institute of Medical Sciences, Bellary.

3. Professor and HOD, Department of Physiology, Vijayanagara Institute of Medical Sciences, Bellary.
4. Professor, Department of Physiology, Vijayanagara Institute of Medical Sciences, Bellary.

5. Assistant Professor, Department of Community Medicine, Vijayanagara Institute of Medical Sciences, Bellary.

\section{NAME ADDRESS EMAIL ID OF THE CORRESPONDING AUTHOR:}

Dr. Ramesh K, Assistant Professor,

Department of Community Medicine,

Vijayanagara Institute of Medical Sciences,

Bellary.

E-mail: ramspsm@yahoo.co.in

Date of Submission: 17/02/2014.

Date of Peer Review: 18/02/2014.

Date of Acceptance: 03/03/2014.

Date of Publishing: 06/03/2014. 